\title{
Model prediksi limbah oli (B3) kendaraan 5 tahun yang akan datang di Kabupaten Sukabumi
}

\author{
Dana Budiman a,1, , Sandi Suswendi a,2, Paikun a,3 \\ ${ }^{a}$ Program Studi Teknik Sipil Universitas Nusa Putra, Cisaat, Sukabumi 43152, Indonesia \\ 1 dana.budiman@nusaputra.ac.idr*; ${ }^{2}$ sandisuswendi@gmail.com; ${ }^{3}$ paikun@nusaputra.ac.id * \\ * Corresponding Author
}

Received 25 February 2021; revised 8 Maret 2021; accepted 15 Juni 2021

\section{ABSTRAK}

Meningkatnya suatu transfortasi yang semakin melesat dari tahun ke tahun menyebabkan terjadinya peningkatan bagi suatu kendaraan bermotor yang akan berdampak terhadap meningkatnya limbah kendarann yang di keluarkan oleh kendaraan tersebut. Limbah yang di keluarakan tersebut merupakan limbah oli (B3) yang berbahaya apabila tidak di kelola dengan baik oleh masyarakat maupun pemerintahan. Limbah B3 merupakan sisa dari proses pengolahan bahan baku yang mengandung bahan berbahaya dan beracun karena sifat atau konsentrasinya secara langsung dapat mencemarkan dan merusak lingkungan hidup, membahayakan lingkungan hidup, kesehatan, kelangsungan hidup manusia serta makhluk hidup lainnya. Penelitian ini bertujuan untuk mengetahui jumlah limbah kendaraan yang di keluarkan di kabupaten sukabumi pada tahun 2020 dan memprediksi limbah oli 5 tahun yang akan datang menggunakan model. Metode yang digunakan adalah deskriptif kuantitatif, dengan pendataan secara langsung pada bengkel-bengkel kendaraan di Sukabumi, serta data jumlah kendaraan pada 5 tahun terakhir di kabupaten Sukabumi. Analisis data untuk menghasilkan model menggunakan analisis regresi. Penelitian ini telah menghasilkan data jumlah limbah oli pada tahun 2020, dan menghasilkan model untuk memprediksi jumlah limbah kendaraan di tahun yang akan datang dengan menggunakan model yaitu rumus persamaan regresi, menggunakan input variabel bebas jumlah tahun kedepan yang akan diprediksi setelah tahun 2020. Setelah limbah oli dapat diprediksi, selanjutnya dapat dijadikan dasar untuk melakukan pengelolaan limbah baik oleh pemerintah, perusahaan atau oleh masyarakat secara individu.

\section{Prediction of oil (B3) waste for 5 years vehicles which will come in Sukabumi district}

\section{ABSTRACT}

The increase in transportation that is getting faster from year to year causes an increase in motorized vehicles, which will impact increasing vehicle waste released by the vehicle. The waste that is released is waste oil (B3) which is dangerous if it is not managed properly by the community and the government. B3 waste is the residue from the processing of raw materials containing hazardous and toxic materials because their nature or concentration can directly pollute and damage the environment, endangering the environment, health, survival of humans, and other living creatures. This study aims to determine the amount of vehicle waste issued in Sukabumi Regency in 2020 and predict oil waste in the next 5 years using the model. The method used is descriptive quantitative, with direct data collection at vehicle workshops in Sukabumi, as well as data on the number of vehicles in the last 5 years in Sukabumi district. Analysis of the data to generate the model using regression analysis. This study has produced data on the amount of waste oil in 2020 and produced a model to predict the amount of vehicle waste in the coming year by using a model, namely the regression equation formula, using the input of the independent variable the number of years ahead which will be predicted after 2020. After the oil waste can be predicted, it can then be used as a basis for managing waste either by the government, companies, or by the community individually. 


\section{Pendahuluan}

Transportasi secara umum diartikan sebagai perpindahan barang atau orang dari satu tempat ke tempat yang lain [1]. Seiring dengan peningkatan kebutuhan masyarakat, maka aktivitas transportasi pun juga meningkat [2]. Hal ini dikarenakan tidak semua fasilitas yang dibutuhkan masyarakat berada pada satu tempat. Kondisi seperti ini mengakibatkan timbulnya pergerakan menuju daerah pemenuhan kebutuhan [3]. Dari sini, dapat dilihat bahwa transportasi sangat penting dalam menunjang aktivitas masyarakat dan turut menentukan perkembangan suatu wilayah [4]. Dengan adanya transportasi yang lancar maka distribusi barang dan jasa juga akan semakin mudah [5]. Namun, tidak selamanya aktivitas transportasi berdampak positif [6]. Aktivitas transportasi juga dapat memberikan akibat negatif. Salah satunya yaitu dampak terhadap lingkungan [7]. Meningkatnya jumlah kendaraan dewasa ini sebagian besar digunakan untuk sarana transportasi [8], yang menyebabkan semakin banyak limbah oli B3 atau oli bekas. Sesuai dengan PP No 101 Tahun 2014 dan oli bekas termasuk Limbah Bahan Berbahaya dan Beracun (B3) [9]. Pada saat ini oli dapat juga dihasilkan dari sampah plastik polietilena melalui proses pirolisis, polietilena lebih dikenal sebagai bahan untuk membuat botol plastik [10]. Masalah yang dialami oleh masyarakat sekarang yaitu semakin banyaknya penggunaan oli oleh masyarakat tanpa solusi yang sederhana yang dapat dilakukan oleh masyarakat, niscaya hal ini akan sangat berdampak besar terhadap jumlah oli bekas yang semakin hari semakin banyak [11].

Menurut Ginting (2007) mengatakan bahwa efek limbah B3 terhadap kesehatan antara lain adalah pernapasan hal tersebut dikarenakan konsentrasi uap yang tinggi akan berbahaya jika dihirup. Konsentrasi yang tinggi dapat mengganggu saluran pernapasan (hidung, tenggorokan dan paru-paru) [12]. Menyebabkan mual, muntah, sakit kepala, pusing, kehilangan koordinasi, rasa dan gangguan saraf lainnya. Paparan dengan konsentrasi akut dapat menyebabkan depresi saraf, pingsan, koma dan atau kematian [13]. Efek limbah B3 juga dapat menyebabkan iritasi pada mata dan kulit. Efek pada kulit dikarenakan limbah B3 menyebabkan dermatitis atau meresap kedalam kulit dan menimbulkan dampak seperti pada pernapasan, selain itu efek kesehatan lainnya yaitu pencernaan dikarenakan konsentrasi limbah bahan berbahaya dan beracun atau B3 pada saluran pencernaan berbahaya jika tertelan, menyebabkan mual, muntah dan gangguan saraf lainnya. Jika produk tertelan dapat menyebabkan kanker paru-paru atau kematian [14].

Berdasarkan permasalahan di atas maka penelitian ini penting untuk di lakukan untuk mengantisipasi masalah limbah oli di kabupaten sukabumi. Penelitian ini bertujuan untuk mengidentifikasi jumlah limbah oli akibat kendaraan bermotor di kabupaten Sukabumi dalam setiap tahun. Selain itu penelitian ini bertujuan untuk menghasilkan model untuk memprediksi jumlah limbah oli akibat kendaraan bermotor pada 5 tahun yang akan datang. Hasil dari penelitian ini berkonstribusi menjadi referensi bagi pemerintah untuk membuat kebijakan mengenai pengolahan limbah oli, serta berkonstribusi terhadap masyarakat yang memampaatkan limbah oli sebagai bahan baku material seperti membuat aspal menggunakan oli bekas [15] atau yang lainnya.

\section{Method}

Penelitian ini dilakukan diwilayah kabupaten Sukabumi. Metode penelitian deskriptif kuantitatif yang di gunakan dalam penelitian ini dengan cara survei langsung ke lapangan untuk mencari data limbah kendaraan yang di hasilkan oleh suatu kendaraan. Data diproses menggunakan bantuan aplikasi dan selanjutnya menggunakan metode statistic analisis regresi untuk menghasilkan model prediksi limbah oli 5 tahun yang akan datang di kabupaten sukabumi. Peta wilayah kabupaten Sukabumi seperti dijelaskan pada Gambar 1. Tahapan penelitian dijelaskan dalam pembahasan lebih lanjut. 


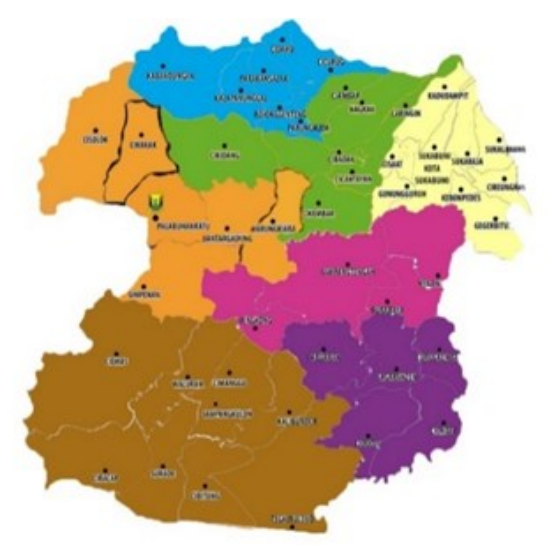

Gambar 1. Peta wilayah kabupaten Sukabumi

\subsection{Alat dan Teknik Pengambilan Data}

Peralatan dan Perlengkapan terdiri dari; (1) Kertas Kuisoner; (2) Balpoin; (3) Papan Tulis; (4) Leptop; (5) Sofware Excel. Cara pengambilan data sample adalah menentukan lokasi pengambilan sample berdasarkan merek kendaraan yang ada di Kabupaten Sukabumi, menentukan mekanik yang akan di wawancara/kuisoner, mencatat jumlah hasil wawancara/kuisoner

\subsection{Perhitungan rata rata limbah oli $B 3$}

Rata-rata hitung $(\mathrm{X})$ atau Mean merupakan ukuran statistik kecenderungan terpusat yang paling sering digunakan [16]. Nilai rata-rata juga sering disebut nilai yang dapat cukup representative dalam distribusi sehingga nilai rata-rata tersebut dianggap nilai sentral dan dapat dipergunakan untuk pengukuran suatu distribusi. Nilai rata-rata hitung ditentukan dengan menggunakan persamaan 1 [17]. $\mathrm{Xt}$ adalah nilai pengukuran dari suatu variat, $\mathrm{X}$ merupakan rata-rata hitung, dan $\mathrm{N}$ adalah jumlah data.

$\mathrm{x}$ rata-rata $=1 / \mathrm{n} \sum_{-}(\mathrm{i}=1)^{\wedge} \mathrm{n} \mathrm{Xi}$

\subsection{Cara menentukan sample}

Dari populasi tersebut ditarik sampel dengan menggunakan simple random sampling (sampel acak sederhana) yaitu cara pengambilan sampel secara acak (random) dengan benar-benar memberikan peluang yang sama. Selanjutnya untuk mendapatkan besaran jumlah sampel dalam penelitian ini menggunakan teori yang dikembangkan oleh Issac dan Michael [16]. Rumus yang digunakan untuk menghitung besarnya sampel yang diperlukan dalam penelitian ini adalah menggunakan rumus Yamane seperti dijelaskan dalam Persamaan 2 [17].

$$
\mathrm{n}=\mathrm{N} /\left(\mathrm{N}\left(\mathrm{d}^{\wedge} 2\right)+1\right)
$$

Keterangan penjelas dari rumus tersebut adalah $\mathrm{n}$ merupakan jumlah sample, $\mathrm{N}$ adalah ukuran populasi, dan d adalah presisi (Perkiraaan Kesalahan yang di perkirakan yaitu 0,1)

\subsection{Bagan Alir Penelitian}

Tahapan penelitian dimulai dari identifikasi masalah dan perumusan masalah, penentuan lokasi penelitian, pengumpulan data yang terdiri dari data primer dan data skunder, analisis data serta analisis statistic regresi untuk menghasilkan model. Untuk memudahkan menjelaskan tahapan penelitian ini secara ringkas disimulasikan pada Gambar 2. 


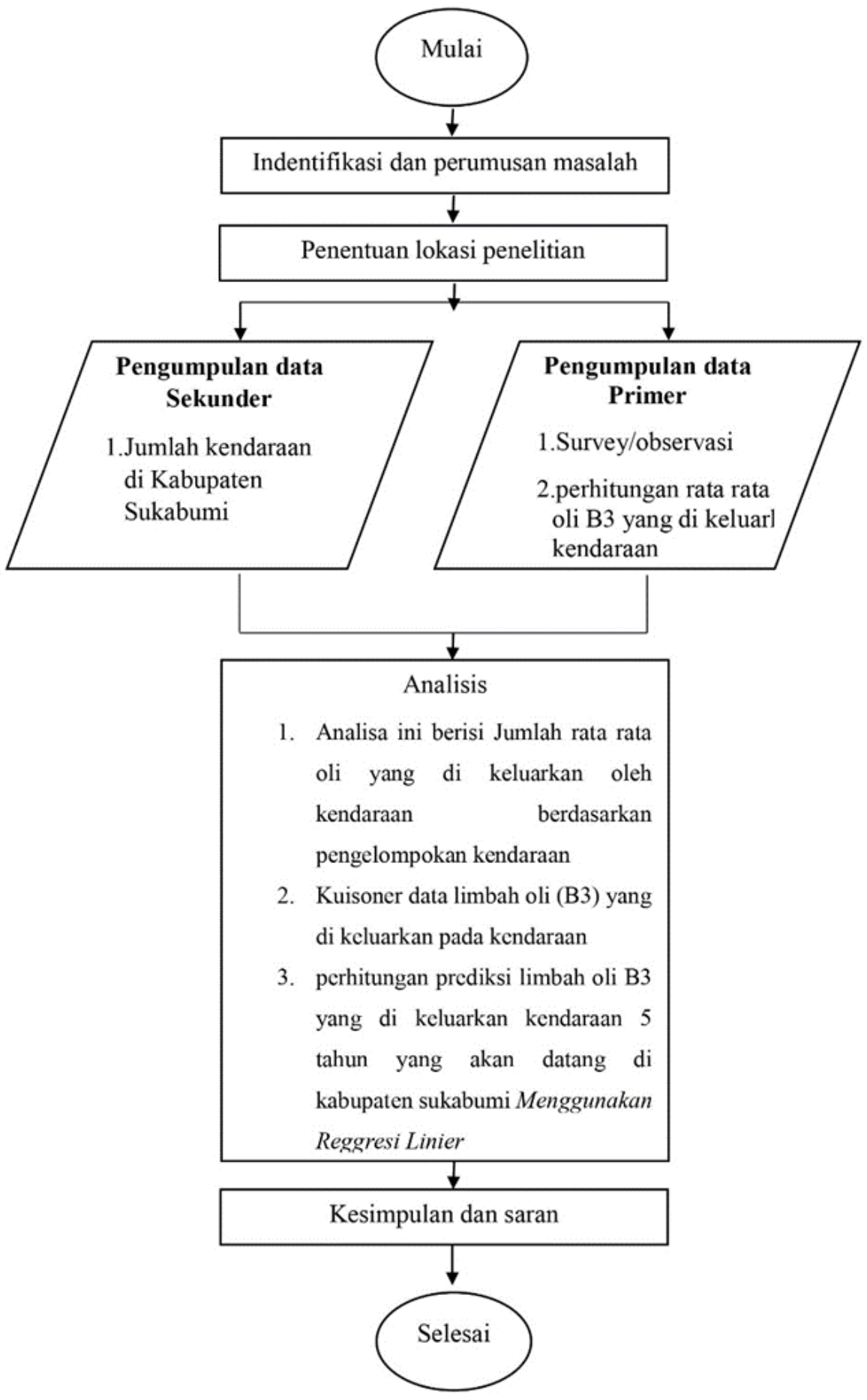

Gambar 2. Gambar alur penelitian

\section{Hasil dan Pembahasan}

\subsection{Data kendaraan di Kabupaten Sukabumi}

Untuk mendapatkan data kendaraan dari Bapenda Jabar (Badan Pendapatan Daerah Jawa Barat) harus mengirimkan formulir permohonan permintaan data yang telah di sediakan oleh Bapenda Jabar yang tertera di situs bapenda.jabarprov.go.id, untuk kendaraan yang di data dalam peneltian ini yaitu kendaraan tahun 2013-2020 seasuai data yang tersedia di Bapenda Jabar, Untuk type kendaraan yang telah di dapat berdasarkan informasi dari Bapenda Jabar yaitu di antaranya: sedan, jeef, minibus, bus, microbus, truck, pickup, sepedamotor, scooter. Jumlah kendaraan berdasarkan jenis kendaraan dari tahun 2013-2020 di jelaskan pada Tabel 1 . 
Tabel 1. Data kendaraan di Kabupaten Sukabumi

\begin{tabular}{cccccc}
\hline No & Tahun & Sedan, Jeep, Minibus & Bus, Microbus & Truck, Pick Up & Sepeda Motor \\
\hline 1 & 2013 & 16.325 & 380 & 13.626 & 321.351 \\
2 & 2014 & 22.391 & 354 & 17.583 & 394.848 \\
3 & 2015 & 25.303 & 371 & 19.991 & 428.351 \\
4 & 2016 & 28.524 & 404 & 20.298 & 465.090 \\
5 & 2017 & 31.715 & 432 & 21.208 & 503.702 \\
6 & 2018 & 34.507 & 425 & 20.544 & 477.197 \\
7 & 2019 & 37.673 & 467 & 20.912 & 492.193 \\
8 & 2020 & 37.085 & 469 & 20.226 & 483.664 \\
Jumlah & & 233.523 & 3302 & 154.388 & 3166.396 \\
\hline
\end{tabular}

Data dalam Tabel 1 di gunakan untuk mencari nilai rata rata limbah pertahunnya oli yang di keluarkan kendaraan berdasarkan type kendaraan dan untuk memprediksi limbah oli (B3) kendaraan 5 tahun kedepan di Kabupaten Sukabumi.

\subsection{Olah data}

Setelah mendapatkan data kendaraan tahun 2013 - 2020 seperti yang dijelaskan pada Tabel 1, langkah selanjutnya yaitu mengolah data menjadi persentase tahunan dengan salah satu bantuan Microsoft Excel dari setiap jenis kendaraan yang tebagi menjadi 4 bagian, di antaranya jenis: 1. sedan, jeef, minubus, 2 . bus, microbus, 3. truck, pickup, 4. sepeda motor. Cara menghitung persentase tahunan menggunakan rumus Persamaan 3 dicontohkan pada data kendaraan sedan, jeep dan minibus yang terdata pada Tabel 1.

Persentase (Jumlah Bagian)/(Jumlah Keseluruhan) x 100\%

Berdasarkan Persamaan 3 dengan sample kendaraan jenis sedan, jeef, minibus tahun 2013 seperti ditampilkan pada Tabel 1, maka persentase kendaraan tahun 2013 dari data tahun 2013-2020 seperti dihitung sebagai berikut:

Persentase $=16,325 / 233,523 \times 100 \%=7 \%$.

Setelah dihitung maka dapat diketahui bahwa persentasi kendaraan sedan, jeep dan minibus sebesar 7\%. Hasil analisis persentase kendaraan secara keseluruhan dengan cara menghitung persentase menggunakan Persamaan 3, dirangkum pada Tabel 2.

Tabel 2. Persentase Kendaraan Berdasarkan Kelompok Jenis Kendaraan

\begin{tabular}{|c|c|c|c|c|c|c|c|c|}
\hline Tahun & $\begin{array}{l}\text { Sedan, Jeep, } \\
\text { Minibus }\end{array}$ & $(\%)$ & $\begin{array}{c}\text { Bus, } \\
\text { Microbus }\end{array}$ & $(\%)$ & $\begin{array}{c}\text { Truc, Pick } \\
\text { Up }\end{array}$ & $(\%)$ & $\begin{array}{l}\text { Sepeda } \\
\text { Motor }\end{array}$ & $(\%)$ \\
\hline 2013 & 16.325 & $7 \%$ & 380 & $12 \%$ & 13.626 & $9 \%$ & 321.351 & $9 \%$ \\
\hline 2014 & 22.391 & $10 \%$ & 354 & $11 \%$ & 17.583 & $11 \%$ & 394.848 & $11 \%$ \\
\hline 2015 & 25.303 & $11 \%$ & 371 & $11 \%$ & 19.991 & $13 \%$ & 428.351 & $12 \%$ \\
\hline 2016 & 28.524 & $12 \%$ & 404 & $12 \%$ & 20.298 & $13 \%$ & 465.090 & $13 \%$ \\
\hline 2017 & 31.715 & $14 \%$ & 432 & $13 \%$ & 21.208 & $14 \%$ & 503.702 & $14 \%$ \\
\hline 2018 & 34.507 & $15 \%$ & 425 & $13 \%$ & 20.544 & $13 \%$ & 477.197 & $13 \%$ \\
\hline 2019 & 37.673 & $16 \%$ & 467 & $14 \%$ & 20.912 & $14 \%$ & 492.193 & $14 \%$ \\
\hline 2020 & 37.085 & $16 \%$ & 469 & $14 \%$ & 20.226 & $13 \%$ & 483.664 & $14 \%$ \\
\hline \multicolumn{2}{|c|}{$\begin{array}{l}\text { Rata-rata persentase kenaikan } \\
\text { kendaraan tiap tahun }(\%)\end{array}$} & $9 \%$ & & $2 \%$ & & $4 \%$ & & $5 \%$ \\
\hline
\end{tabular}

Hasil persentase tahunan seperti ditampilkan pada Tabel 2 ini untuk mengetahui peningkatan kendaraan jenis sedan, jeef, minibus, bus, microbus, truck, pickup, sepedamotor setiap tahun, untuk mempermudah untuk melihat naik atau turunnya jumlah kendaraan dari tahun ke tahun di Kabupaten Sukabumi. Kenaikan jumlah kendaraan setiap dan persentase rata-rata kenaikan tiap tahun kendaraan bermotor di Kabupaten Sukabumi seperti dijelaskan pada Tabel 2, menunjukan bahwa persentase rata- 
rata kenaikan kendaraan untuk jenis kendaraan sedan, jeep dan minibus adalah $9 \%$, bus dan minibus $2 \%$, truck dan pick up $4 \%$, dan sepeda motor $5 \%$.

\subsection{Data Kendaraan Berdasarkan Jenis Kendaraan}

Data kendaraan berdasarkan sumber yang telah dijelaskan pada Tabel 1 tidak terperinci dengan jelas jumlah kendaraan berdasarkan jenis kendaraan, melainkan data berdasarkan kelompok jenis kendaraan, sedangkan penggunaan oli akan berbeda-beda dalam tiap jenis kendaraan, sehingga dalam tahap ini mengasumsikan jumlah tiap-tiap jenis kendaraan dengan menghitung menggunakan rumus Persamaan 4.

$$
\text { Jumlah jenis kendaraan tiap tahun }=\frac{\text { jumlah kendaraan } n}{\text { jumlah kelompok kendaraan }}
$$

Diketahui jumlah jenis sedan, jeef, minibus tahun 2013 adalah 16.325 unit, dan banayaknya jenis kendaraan berdasarkan kelompok kendaraan adalah 3, yaitu sedan, jeef, dan minibus. Berdasarkan Persamaan 4 maka kendaraan jenis sedan adalah:

Jumlah kendaraan jenis sedan tiap tahun $=\frac{16.325}{3}$ atau 5.442 unit

Berdasarkan asumsi menggunakan analisis Persamaan 4, maka dapat diketahui kendaraan jenis sedan pada tahun 2013 adalah 5.442, jeep 5.442, minibus 5.442 unit. Selanjutnya jumlah kendaraan jenis lain dalam tiap tahun dihitung secara keseluruhan menggunakan rumus Persamaan 4. Hasil analisis data jumlah kendaraan berdasarkan jenis kendaraan dirangkum dalam Tabel 3.

Tabel 3. Jumlah Kendaraan Berdasarkan Jenis Kendaraan

\begin{tabular}{ccccccccc}
\hline Tahun & Sedan & Jeep & Minibus & Bus & Microbus & Truck & Pick Up & Sepeda Motor \\
\hline 2013 & 5.442 & 5.442 & 5.442 & 190 & 190 & 6.813 & 6.813 & 321.351 \\
2014 & 7.464 & 7.464 & 7.464 & 177 & 177 & 8.792 & 8.792 & 394.848 \\
2015 & 8.434 & 8.434 & 8.434 & 185,5 & 186 & 9.996 & 9.996 & 428.351 \\
2016 & 9.508 & 9.508 & 9.508 & 202 & 202 & 10.149 & 10.149 & 465.090 \\
2017 & 10.572 & 10.572 & 10.572 & 216 & 216 & 10.604 & 10.604 & 503.702 \\
2018 & 11.502 & 11.502 & 11.502 & 212,5 & 213 & 10.272 & 10.272 & 477.197 \\
2019 & 12.558 & 12.558 & 12.558 & 233,5 & 234 & 10.456 & 10.456 & 492.193 \\
2020 & 12.362 & 12.362 & 12.362 & 234,5 & 235 & 10.113 & 10.113 & 483.664 \\
Jumlah & 77.841 & 77.841 & 77.841 & 1.651 & 1.651 & 77.194 & 77.194 & 3.566 .396 \\
\hline
\end{tabular}

Data pada Tabel 3 ini di gunakan untuk mempermudah mencari nilai rata rata limbah oli kendaraan pertahun berdasarkan jenis kendaraan yang ada di Kabupaten Sukabumi.

\subsection{Menentukan Jumlah Oli Kendaraan Bedasarkan Klasifikasi Kendaraan}

Berdasarkan pada hasil survei klasifikasi jumlah jenis kendaraan tidak di ketahui, sedangkan tiap jenis kendaraan mengeluarkan limbah oli yang berbeda-beda. Suatu contoh kendaraan jenis sedan terdapat 3 katagori dalam mengeluarkan oli yaitu 3 ltr, 3,5 ltr dan 4 ltr, oleh karena itu perlu mengelompokan jenis kendaraan berdasarkan jumlah oli yang dikeluarkan dari masing-masing jenis kendaraan. Cara mengelompokan dapat dihitung menggunakan Persamaan 5.

Jumlah kendaraan berdasarkan oli yang dikeluarkan $=\frac{\text { jumlah } \text { kendaraan } n / \text { jenis }}{\text { jumlah kelompok pengeluaran oli }}$

Diketahui jumalah kendaraan sedan than 2013 adalah 5.442, kelasifikasi kendaraan sedan berdasarkan oli yang dikeluarkan adalah 3 jenis yaitu sedan 3 ltr, sedan 3,5 ltr, sedan 4 ltr, maka menggunakan Persamaan 5 jumlah kendaraan sedan tahun 2013 yang mengeluarkan oli 3 ltr adalah:

Jumlah kendaraan oli 3 liter $=\frac{5.442}{3}$ atau 1.814 unit.

Maka jenis kendaraan sedan yang mengeluarkan oli 3 ltr sebanyak 1.814 unit, begitu juga jumlah kendaraan sedan yang mengeluarkan oli 3,5 liter dan 4 liter. Untuk menghitung jumlah jenis kendaraan berdasarkan kelompok kendaraan dalam mengeluarkan oli pada tahun berikutnya dapat menggunakan Persamaan 5 yang di contohkan pada jenis kendaraan sedan yang mengeluarkan oli 3 liter, demikian juga menghitung jumlah kendaraan pada jenis kendaraan lainnya seperti jeep, minibus, bus, microbus, truck, 
pick up, serta sepeda motor. Hasil analisis jumlah kendaraan berdasarkan jenis kendaraan dan kelompok kendaraan dalam mengeluarkan limbah oli diterangkan dalam Tabel 4.

Tabel 4. Kelompok Jenis Kendaraan Berdasarkan Jumlah Oli Bekas Yang Dikeluarkannya

\begin{tabular}{|c|c|c|c|c|c|c|c|c|c|}
\hline \multirow{2}{*}{\multicolumn{2}{|c|}{ Jenis Kendaraan }} & \multicolumn{8}{|c|}{$\begin{array}{c}\text { Jumlah kendaraan berdasarkan limbah oli yang dikeluarkan tahun } 2013 \\
\text { sampai } 2020\end{array}$} \\
\hline & & 2013 & 2014 & 2015 & 2016 & 2017 & 2018 & 2019 & 2020 \\
\hline \multirow{4}{*}{ Sedan } & $3 \mathrm{~L}$ & 1.814 & 2.488 & 2.811 & 3.169 & 3.524 & 3.834 & 4.186 & 4.121 \\
\hline & $3,5 \mathrm{~L}$ & 1.814 & 2.488 & 2.811 & 3.169 & 3.524 & 3.834 & 4.186 & 4.121 \\
\hline & $4 \mathrm{~L}$ & 1.814 & 2.488 & 2.811 & 3.169 & 3.524 & 3.834 & 4.186 & 4.121 \\
\hline & $3 \mathrm{~L}$ & 1.814 & 2.488 & 2.811 & 3.169 & 3.524 & 3.834 & 4.186 & 4.121 \\
\hline \multirow{2}{*}{ Jeep } & $3,5 \mathrm{~L}$ & 1.814 & 2.488 & 2.811 & 3.169 & 3.524 & 3.834 & 4.186 & 4.121 \\
\hline & $4 \mathrm{~L}$ & 1.814 & 2.488 & 2.811 & 3.169 & 3.524 & 3.834 & 4.186 & 4.121 \\
\hline \multirow{3}{*}{ Minibus } & $3 \mathrm{~L}$ & 2.721 & 3.732 & 4.217 & 4754 & 5286 & 6.279 & 6.279 & 6.181 \\
\hline & $4 \mathrm{~L}$ & 2.721 & 3.732 & 4.217 & 4754 & 5286 & 6.279 & 6.279 & 6.181 \\
\hline & $8 \mathrm{~L}$ & 48 & 44 & 47 & 51 & 54 & 53 & 59 & 59 \\
\hline \multirow{3}{*}{ Bus } & $18 \mathrm{~L}$ & 48 & 44 & 47 & 51 & 54 & 53 & 59 & 59 \\
\hline & $25 \mathrm{~L}$ & 48 & 44 & 47 & 51 & 54 & 53 & 59 & 59 \\
\hline & $30 \mathrm{~L}$ & 48 & 44 & 47 & 51 & 54 & 53 & 59 & 59 \\
\hline Microbus & $6 \mathrm{~L}$ & 190 & 177 & 186 & 202 & 216 & 213 & 234 & 235 \\
\hline \multirow[t]{2}{*}{ Truck } & $7 \mathrm{~L}$ & 6.813 & 8.792 & 9.996 & 10.149 & 10.604 & 10.272 & 10.456 & 10.113 \\
\hline & $3 \mathrm{~L}$ & 2.271 & 2.931 & 3332 & 3.383 & 3.535 & 3.424 & 3.485 & 3.371 \\
\hline \multirow{2}{*}{ Pick Up } & $3,5 \mathrm{~L}$ & 2.271 & 2.931 & 3332 & 3.383 & 3.535 & 3.424 & 3.485 & 3.371 \\
\hline & $4 \mathrm{~L}$ & 2.271 & 2.931 & 3332 & 3.383 & 3.535 & 3.424 & 3.485 & 3.371 \\
\hline \multirow{3}{*}{$\begin{array}{l}\text { Sepeda } \\
\text { Motor }\end{array}$} & $0,8 \mathrm{~L}$ & 107.117 & 131.616 & 142.784 & 155.030 & 167.901 & 159.066 & 164.064 & 161.221 \\
\hline & $1 \mathrm{~L}$ & 107.117 & 131.616 & 142.784 & 155.030 & 167.901 & 159.066 & 164.064 & 161.221 \\
\hline & $2 \mathrm{~L}$ & 107.117 & 131.616 & 142.784 & 155.030 & 167.901 & 159.066 & 164.064 & 161.221 \\
\hline
\end{tabular}

Hasil dari perhitungan yang di tampilkan pada Tabel 4 ini di gunakan untuk mencari nialai rata-rata dan untuk menghitung jumlah limbah oli (B3) kendaran pada tahun 2013-2020.

\subsection{Rata Rata Limbah Oli (B3) Berdasarkan Jenis Kendaraan}

Setelah di ketahui jumlah oli yang di keluarkan dari masing-masing jenis kendaraan sepeti telah diterangkan pada Tabel 4, maka langkah selanjutnya yaitu menentukan nilai rata rata limbah oli (B3) yang di keluarkan kendaraan tersebut, rumus menghitung rata-rata menggunakan Persamaan 6 berikut:

$$
M \frac{J D O K}{B D}
$$

$\mathrm{M}$ adalah Mean, JDK merupakan jumlah sisa oli yang di keluarkan kendaraan, dan BD adalah banyak data

Setelah diketahui rata-rata limbah oli yang di keluarkan dari masing-masing jenis kendaraan di atas maka langkah selanjutnya yaitu menentukan nilai rata-rata ganti oli kendaraan perbulan berdasarkan jenis kendaraan, menggunakan rumus rata-rata Persamaan 1. Langkah berikutnya adalah menghitung jumlah limbah oli perunit dalam 1 tahun berdasarkan jenis kendaraan yang terdata pada Tabel 4 di atas. Sebagai contoh disimulasikan menghitung limbah oli pada jenis kendaraan sedan 3,5 ltr menggunakan Persamaan 7.

(Nilai rata rata oli yang di keluarkan) X (Ganti oli dalam 1 tahun)

Diketahui kendaraan jenis sedan ganti oli dalam 1 tahun adalah 12 kali, rata-rata sisa oli yang di keluarkan adalah 3,5 ltrr, maka jumlah limbah oli yang dikeluarkan dalam 1 tahun adalah:

$3 \times 12=36$ liter

Berdasarkan perhitungan menggunakan Persamaan 7 seperti yang telah dicontohkan diatas, secara keseluruhan limbah oli yang dikeluarkan oleh kendaraan dihitung dalam setiap tahun dari tahun 20132020. Hasil proses data dapat diketahui bahwa limbah oli dalam tiap tahun yang dikeluarkan oleh kendaraan bermotor seperti dijelaskan pada Tabel 5 . 
Tabel 5. Limbah Oli Dari Kendaraan Tahun 2013-2020 Di Kabupaten Sukabumi

\begin{tabular}{|c|c|c|c|c|c|c|c|c|c|}
\hline \multirow{2}{*}{\multicolumn{2}{|c|}{$\begin{array}{c}\text { Jenis } \\
\text { Kendaraan }\end{array}$}} & \multicolumn{8}{|c|}{ Jumlah Limbah Kendaraan Dtahun 2013 sampai 2020 ( liter) } \\
\hline & & 2013 & 2.014 & 2015 & 2016 & 2017 & 2018 & 2019 & 2020 \\
\hline \multirow{3}{*}{ Sedan } & $3 \mathrm{~L}$ & 65.304 & 89.568 & 101.208 & 114.096 & 126.864 & 138.024 & 150.696 & 148.344 \\
\hline & $3,5 \mathrm{~L}$ & 76.188 & 104.496 & 118.076 & 133.112 & 148.008 & 161.028 & 175.812 & 173.068 \\
\hline & $4 \mathrm{~L}$ & 87.072 & 119.424 & 134.944 & 152.128 & 169.152 & 184.032 & 200.928 & 197.792 \\
\hline \multirow{3}{*}{ Jeep } & $3 \mathrm{~L}$ & 65.304 & 89.568 & 101.208 & 114.096 & 126.864 & 138.024 & 150.696 & 148.344 \\
\hline & $3,5 \mathrm{~L}$ & 76.188 & 104.496 & 118.076 & 133.112 & 148.008 & 161.028 & 175.812 & 173.068 \\
\hline & $4 \mathrm{~L}$ & 87.072 & 119.424 & 134.944 & 152.128 & 169.152 & 184.032 & 200.928 & 197.792 \\
\hline \multirow{2}{*}{ Minibus } & $3 \mathrm{~L}$ & 97.956 & 134.352 & 151.812 & 171144 & 253728 & 226.044 & 226.044 & 222.516 \\
\hline & $4 \mathrm{~L}$ & 130.608 & 179.136 & 202.416 & 228192 & 253728 & 301.392 & 301.392 & 296.688 \\
\hline \multirow{4}{*}{ Bus } & $8 \mathrm{~L}$ & 1.520 & 1.416 & 1.488 & 1.616 & 1728 & 1.704 & 1.872 & 1.880 \\
\hline & $18 \mathrm{~L}$ & 3.420 & 3.186 & 3.348 & 3.636 & 3888 & 3.834 & 4.212 & 4.230 \\
\hline & $25 \mathrm{~L}$ & 4.750 & 4.425 & 4.650 & 5.050 & 5400 & 5.325 & 5.850 & 5.875 \\
\hline & $30 \mathrm{~L}$ & 5.700 & 5.310 & 5.580 & 6.060 & 6480 & 6.390 & 7.020 & 7.050 \\
\hline Microbus & $6 \mathrm{~L}$ & 1.140 & 1.062 & 1.116 & 1212 & 1296 & 1.278 & 1.404 & 1.410 \\
\hline \multirow[t]{2}{*}{ Truck } & $7 \mathrm{~L}$ & 47.691 & 61.544 & 69.972 & 71.043 & 381.744 & 71.904 & 62.736 & 70.791 \\
\hline & $3 \mathrm{~L}$ & 81.756 & 105.504 & 119.952 & 365.364 & 127.248 & 123.264 & 125.472 & 121.356 \\
\hline \multirow[t]{2}{*}{ Pickup } & $3,5 \mathrm{~L}$ & 95.382 & 123.088 & 139.944 & 121.788 & 148.456 & 143.808 & 146.384 & 141.582 \\
\hline & $4 \mathrm{~L}$ & 109.008 & 140.672 & 159.936 & 142.086 & 169.664 & 164.352 & 167.296 & 161.808 \\
\hline \multirow{3}{*}{$\begin{array}{l}\text { Sepeda } \\
\text { motor }\end{array}$} & $0,8 \mathrm{~L}$ & 1.028 .323 & 1.263 .514 & 1.370 .723 & 1.488 .288 & 1.611 .846 & 1.527 .030 & 1.575 .018 & 1.547 .725 \\
\hline & $1 \mathrm{~L}$ & 1.285 .404 & 1.579 .392 & 1.713 .404 & 1.860 .360 & 2.014 .808 & 1.908 .788 & 1.968 .772 & 1.934 .656 \\
\hline & $2 \mathrm{~L}$ & 2.570 .808 & 3.158 .784 & 3.426 .808 & 3.720 .720 & 4.029 .616 & 3.817 .576 & 3.937 .544 & 3.869 .312 \\
\hline \multicolumn{2}{|c|}{$\begin{array}{l}\text { Jumlah limbah } \\
\text { oli/tahun }\end{array}$} & 5.920 .594 & 7.388 .361 & 8.079 .605 & 8.985 .231 & 9.897 .678 & 9.268 .857 & 9.585 .888 & 9.425 .287 \\
\hline
\end{tabular}

\subsection{Model Prediksi Limbah Oli 5 Tahun Mendatang}

Setelah diketahui jumlah limbah oli dalam tiap tahun maka perlu diketahui kenaikan jumlah limbah oli dalam tiap tahun. Cara menghitung kenaikan limbah oli dalam tiap tahun adalah dengan cara menghitung selisih antara jumlah limbah tahun saat ini dengan jumlah limbah oli pada tahun sebelumnya, suatu contoh, diketahui jumlah limbah oli pada tahun 2014 adalah 7.388.361 ltr, sedangkan jumlah limbah oli pada tahun sebelumnya yaitu pada tahun 2013 adalah 5.920 .595 ltr seperti ditunjukan pada Tabel 5, maka kenaikan jumlah limbah oli dalam 1 tahun adalah 7.388.361-5.920.595 $=1.467 .767$ ltr. Selisih limbah oli dalam tiap tahun selanjutnya dijumlahkan kemudian dibagi banyaknya tahun pendataan untuk mengetahui rata-rata kenaikan jumlah limbah oli dalam setiap tahun. Selisih limbah oli dalam setiap tahun dan rata-rata kenaikan limbah oli setiap tahun diterangkan dalam Tabel 6.

Tabel 6. Kenaikan Limbah Oli Setiap Tahun dan Rata-rata Kenaikan Limbah Oli Pertahun

\begin{tabular}{ccc}
\hline Tahun & Jml Limbah Oli/Tahun & Selisih/Tahun \\
\hline 2013 & 5.920 .594 & 0 \\
2014 & 7.388 .361 & 1.467 .767 \\
2015 & 8.079 .605 & 691.244 \\
2016 & 8.985 .231 & 905.626 \\
2017 & 9.897 .678 & 912.447 \\
2018 & 9.268 .857 & -628.821 \\
2019 & 9.585 .888 & 317.031 \\
2020 & 9.425 .287 & -160.601 \\
\multicolumn{2}{c}{ Kenaikan rata-rata/tahun } & 500.670
\end{tabular}

Hasil analisis seperti yang ditunjukan pada Tabel 6, diketahui bahwa rata-rata kenaikan limbah oli pertahun adalah 500.670 ltr. Cara menghitung rata-rata kenaikan limbah oli pertahun dapat dilakukan menggunakan Persamaan 8.

$$
\text { Rata }- \text { rata }=\Sigma \frac{k}{n}
$$

Penjelasan persamaan tersebut adalah $\mathrm{k}$ sebagai jumlah selisih tiap $\mathrm{n}$, dan $\mathrm{n}$ merupakan jumlah tahun.

Menggunakan Persamaan 8 kenaikan rata-rata/tahun seperti di tunjukan pada Tabel 6, menghitungnya adalah: 
$\frac{3.504 .693}{7}=500.670$

Sehingga diketahui bahwa kenaikan limbah oli rata-rata tiap tahun adalah 500.670 ltr.

Setelah diketahui bahwa jumlah limbah oli pada tahun 2020 adalah 9.425.287 ltr seperti ditunjukan pada Tabel 5, dan rata-rata kenaikan limbah oli pertahun adalah 5000.760 ltr seperti yang ditunjukan pada Tabel 6, maka untuk memprediksi jumlah limbah oli pada tahun mendatang atau 5 tahun yang akan datang yaitu tahun 2025 perlu membuat model persamaan matematik [18]. Model persamaan ini menggunakan data dasar dari jumlah limbah oli pada data terakhir tahun 2020 yaitu 9.425 .287 dan menggunakan data rata-rata kenaikan limbah oli pertahun yaitu 500.670, dengan demikian maka model matematiknya adalah seperti pada Persamaan 9.

$$
\mathrm{F}=\mathrm{P}+\mathrm{Dn}
$$

F adalah jumlah limbah oli dimasa mendatang, P merupakan jumlah limbah oli tahun 2020, dan D adalah rata-rata kenaikan limbah oli tiap tahun, serta n merupakan jumlah tahun yang akan diprediksi. Apabila menggunakan model matematik Persamaan 9 maka jumlah limbah oli 5 tahun yang akan datang dari tahun 2020, yaitu jumlah limbah oli pada tahun 2025 dapat dihitung sebagai berikut:

$$
\begin{aligned}
& F=9.425 .287+5000.760 \times 5 \\
& F=11.928 .637
\end{aligned}
$$

Sehingga jumlah limbah oli 5 tahun yang akan datang atau pada tahun 2025 adalah sebanyak 11.928.637 ltr. Untuk menghitung jumlah limbah oli pada tahun 2021 maka menggunakan Persamaan 9 dengan nilan $\mathrm{n}=1$, menghitung limbah oli pada tahun 2022 nilai $\mathrm{n}=2$, menghitung limbah oli pada tahun 2023 nilai $\mathrm{n}=3$, menghitung limbah oli pada tahun 2023 nila $\mathrm{n}=4$, dan menghitung limbah oli pada tahun 2025 nilai $\mathrm{n}=5$. Jumlah limbah oli akibat kendaraan bermotor di Kabupaten Sukabumi pada tahun 2021-2025 dapat diprediksi seperti ditampilkan pada Tabel 7.

Tabel 7. Prediksi Jumlah Limbah Oli di Kabupaten Sukabumi Pada Tahun 2021-2025 Menggunakan Model

\begin{tabular}{ccc}
\hline Tahun & Cara Hitung & Jml Limbah Oli/Tahun \\
\hline 2021 & $\mathrm{~F}=9.425 .287+(500.670 \times 1)$ & 9.925 .957 \\
2022 & $\mathrm{~F}=9.425 .287+(500.670 \times 2)$ & 10.426 .627 \\
2023 & $\mathrm{~F}=9.425 .287+(500.670 \times 3)$ & 10.927 .297 \\
2024 & $\mathrm{~F}=9.425 .287+(500.670 \times 4)$ & 11.427 .967 \\
2025 & $\mathrm{~F}=9.425 .287+(500.670 \times 5)$ & 11.928 .637 \\
\hline
\end{tabular}

\section{Kesimpulan}

Dengan meningkatnya jumlah kendaraan di Kabupaten Sukabumi ini menyebabkan semakin banyaknya limbah oli yang berbahaya bagi kesehatan manusia dan mahluk hidup lainnya, limbah tersebut merupakan limbah (B3) yang dikeluarkan oleh kendaraan. Jumlah limbah oli dari tahun ketahun akan mengalami peningkatan. Penelitian ini telah mengidentifikasi adanya jumlah limbah oli yang diakibatkan oleh kendaraan yang melakukan pergantian oli pada kendaraannya di Kabupaten Sukabumi pada tahun 2013 sampai dengan tahun 2020. Penelitian ini juga telah menghasilkan model matematik untuk memprediksi jumlah limbah oli (B3) kendaraan 5 tahun yang akan datang. Jumlah limbah oli pada tahun 2020 dan kenaikan rata-rata limbah oli pertahun menjadi koefisien pada model untuk memprediksi jumlah limbah oli yang akan datang. Model untuk memprediksi jumlah limbah oli di kabupaten Sukabumi adalah $\mathrm{F}=\mathrm{P}+\mathrm{Dn}$, dengan pengertian $\mathrm{F}$ adalah jumlah limbah oli yang akan di prediksi pada tahun yang akan datang, P adalah jumlah limbah oli pada tahun 2020 yaitu 9.425.287, D adalah ratarata jumlah kenaikan oli pertahun yaitu 500.670, dan $\mathrm{n}$ adalah jumlah tahun yang akan di prediksi setelah tahun 2020. Model yang dihasilkan dalam penelitian ini dapat dipergunakan untuk memprediksi jumlah limbah oli dimasa yang akan datang, yang selanjutnya dapat berkontribusi bagi pemangku kebijakan untuk membuat ketentuan tentang pengelolaan limbah oli, serta berkonstribusi bagi masyarakat secara umum yang memanfaatkan limbah oli sebagai bahan baku untuk memproduksi sebuah produk. 


\section{Daftar Pustaka}

[1] S. Surajiman, "Tanggung Jawab Pengangkut Terhadap Penumpang dalam Angkutan Pariwisata (Studi Pada Perusahaan Pengangkutan PT Rezeki Trans Wisata di Jogjakarta)." Akses Google Scholar

[2] M. Kadarisman, A. Gunawan, and I. Ismiyati, "Kebijakan Manajemen Transportasi darat dan dampaknya terhadap perekonomian masyarakat di Kota Depok," J. Manaj. Transp. Logistik, vol. 3, no. 1, pp. 41-58, 2016. doi: 10.25292/j.mtl.v3i1.140

[3] L. R. Septiana, "Peningkatan Kinerja Rantai Pasok Bawang Merah (Studi Kasus: Kabupaten Brebes)," J. Teknol. Ind. Pertan., vol. 27, no. 2, 2017. doi: 10.24961/j.tek.ind.pert.2017.27.2.125

[4] B. Jatmika, M. Pallah, N. Akmaliyah, A. Sardi, R. F. K. Barkah, and I. A. Darmawan, "The Evaluation on the Saturation Degree on Pelabuhan II Street of Sukabumi City," in 2018 International Conference on Computing, Engineering, and Design (ICCED), 2018, pp. 208-211. doi: 10.1109/ICCED.2018.00048

[5] K. J. Faah, "Aplikasi Metode Transportasi untuk Optimasi Biaya Serta Emisi pada Pendistribusian Material Proyek Konstruksi Jalan Lingkungan Kawasan Kota Kupang," 2016. Akses Google Scholar

[6] S. Sentiyaki et al., "Alat Penyaring Karbon Monoksida pada Knalpot Kendaraan Bermotor dengan Menggunakan Adsorben Alami Ekstrak Daun Trembesi," J. Chem. Process Eng., vol. 3, no. 1, pp. 38-42, 2018. doi: 10.33536/jcpe.v3i1.192

[7] J. F. Momongan, P. H. Gosal, and V. Kumurur, "Efektivitas jalur hijau dalam menyerap emisi gas rumah kaca di Kota Manado," Spasial, vol. 4, no. 1, pp. 36-43, 2017. Akses Google Scholar

[8] A. R. Mediansyah, "Jaringan Kebijakan Publik Implementasi Kebijakan Transportasi di Kota Makassar," JAKPP (Jurnal Anal. Kebijak. Pelayanan Publik), pp. 14-22, 2017. Akses Google Scholar

[9] I. W. Murti and A. H. Ibrahim, "Identifikasi Bahaya dan Perancangan Tempat Penyimpanan Sementara (TPS) Limbah B3 Proses Sandblasting Di PT Swadaya Graha," ENERGY, vol. 8, no. 1, pp. 1-7, 2018. Akses Google Scholar

[10] D. Wulandari, "Rancang bangun reaktor pirolisis guna konversi sampah plastik jenis polipropilen menjadi bahan bakar cair." Politeknik Negeri Sriwijaya, 2019. Akses Google Scholar

[11] D. Amin, Y. Gaos, and S. Harahap, "Optimasi dan rancang bangun destilasi untuk pemanfaatan limbah oli bekas kendaraan," Teknobiz J. Ilm. Progr. Stud. Magister Tek. Mesin, vol. 8, no. 2, pp. 76-81, 2018. doi: 10.35814/teknobiz.v8i2.898

[12] T. H. Ichtiakhiri and S. Sudarmaji, "B3 Waste Management and Health Workers Complaint In. Inka (Persero) Madiun City," J. Kesehat. Lingkung., vol. 8, no. 1, pp. 118-127, 2015. doi: 10.20473/jkl.v8i1.2015.118-127

[13] S. M. D. Rahmadhani, M. Diana, M. D. Lestari, and R. Riesmiyatiningdyah, "Asuhan Keperawatan pada Ny. D dengan diagnosa medis cerebro vaskular accident bleeding di ruang krissan RSUD Bangil Pusuruhan." Akademi Keperawatan Kerta Cendekia Sidoarjo, 2020. Akses Google Scholar

[14] O. R. Pinontoan and O. J. Sumampouw, Dasar Kesehatan Lingkungan. Deepublish, 2019. Akses Google Scholar

[15] S. C. Paikun, Sihotang Rico, Rahmawati Debby and Herlina Lina, "Pure Experiments Creating New Types of Asphalt Using Oil Waste, Resin Stones and Plant Branchs," in 2020 6th International Conference on Computing Engineering and Design (ICCED), 2020, pp. 1-6. doi: 10.1109/ICCED51276.2020.9415779

[16] Y. Fitriyana, "Pengaruh lingkungan keluarga dan pemanfaatan internet sebagai sumber belajar terhadap motivasi belajar siswa pada mata pelajaran ekonomi kelas xi sma negeri 1 salaman," OIKONOMIA-Jurnal Pendidik. Ekon., vol. 8, no. 2, 2019. Akses Google Scholar

[17] H. A. Imron, "Peran Sampling dan Distibusi Data dalam Penelitian Komunikasi Pendekatan Kuantitatif," J. Stud. Komun. dan media, vol. 21, no. 1, pp. 111-126, 2017. doi: 10.31445/jskm.2017.210109

[18] Paikun, M. Kahpi, R. Krisnawati, A. Agustian, R. Rohimat, and Jasmansyah, "Estimates of material need on houses construction using regression model program," in Proceedings - 2018 4th International Conference on Computing, Engineering, and Design, ICCED 2018, 2019, pp. 93-98. doi: 10.1109//CCED.2018.00027 